\title{
Why Sustained Economic Growth in East Asia?
}

LI XING

\section{Introduction}

Through the 1950s and 1960s, Japan surprised the whole world by demonstrating its economic power with growth rates of ten percent or more. In the 1960s and 1970s, the East Asian ${ }^{1}$ industrialized countries - South Korea, Taiwan, Singapore and Hong Kong - also surprised the world by demonstrating their abilities to achieve similar progress with an average growth rate close to ten percent. During the 1980s, Japan's growth slowed to four percent, but the little dragons were still able to keep the economic growth at seven percent. Japanese economists like to refer to the phenomenon of East Asian growth as the "flying-geese pattern" - with Japan at the head followed by the four high-flying newly industrialized economies (NIEs, also called NICs) ${ }^{2}$ - South Korea, Taiwan, Hong Kong and Singapore - and then the ASEAN countries. All together, the rapid economic development in East Asia is one of the biggest success stories of the twentieth century.

The four East Asian NICs have recently been joined by a new generation of developing dragons - Thailand, Malaysia and Indonesia. These Seven Dragons are leading the world in economic growth and gradually coming out of Third World poverty and approaching First World prosperity.

Most interesting to the world is China. After its military crackdown on the student democratic movement in June 1989, China faced international condemnation and economic sanction. Its national economic development was predicted to face a major setback. However, surprisingly, China's economy has been constantly growing since 1989. Even more impressively, while much of the world is in recession, the three Chinas - mainland China, Hong Kong and Taiwan - are booming. Southern China is the fastest-growing economy in the world and is quickly integrating itself with Hong 
Li Xing

Kong's economy. The South's Guangdong Province, for instance, has averaged four-teen percent real growth since 1985; and Shenzhen, the economic zone next to Hong Kong, is growing by forty percent a year.

Some Western analysts hold that these developing countries are using low-wage labour to produce low-quality goods that are dumped on the markets of the industrialized world. This assumption is seemingly out of date. Malaysia, for example, has become the world's leading exporter of computer chips and the third largest producer of semiconductors after Japan and the US; and in Thailand electronic goods have replaced textiles as the leading export.

The aim of this article is to find and analyze some explanations to this interesting phenomenon of regional sustained economic growth by focusing on the dynamics of East Asian regional economic relations. Why does sustained economic growth only occur in this region but not in other regions? Many scholars have begun to notice the peculiar East Asian economic development and industrial relations. This interesting dynamic phenomenon can be seen from three closely inter-related and somehow overlapping types of economic relation:

(1) The dynamics of "take-over", "ladder" and "chain" pattern of intra-regional economic relations.

(2) The dynamics of intra-regional market and trade.

(3) The dynamics of intra-regional capital market and investment.

These close nation-to-nation and region-to-region economic relations are very unique in the way that they reveal two aspects of strength of East Asian economic dynamics. The first is sustained economic growth, and the second is spatial expansion. Sustained economic growth means that in the past several decades, East Asia has been able to keep a high growth rate. The world economy has witnessed several setbacks in the past especially by the two oil crises in the 1970s. However, Japan and the NICs could surprisingly be able to keep a sustained high economic growth. Spatial expansion shows that East Asia's economic growth, starting from Japan, has been moving towards south and expanding in a string-of-beads style. A chained curve-type growth line is thus formed: Japan South Korea - (China - Taiwan - Hong Kong) - Thailand - Singapore Malaysia - Indonesia. 
In the 1990s, the Japanese growth rate has decreased for a few years, but the Korean and Taiwanese economies are continuing to reveal their vitality and keep medium-high growth rates. China has presented a historical surge in its economic performance since the beginning of the 1990s, but its growth engine seems to be overheated creating new economic and social problems. So China's problem these days is how to cool down the over-heated economic growth rather than accelerate it. This East Asian growth line is expected to continue to expand both in time and space. More East Asian countries and regions such as Vietnam and China's inner regions are most likely to join in the growth line in the near future.

\section{Some Theoretical Explanations}

A unique feature of East Asian economic growth is that there has emerged a development pattern with both vertical and horizontal divisions of labour and manufacture to utilize the economic complementarities among economies of different development levels and resource endowments. The interdependent relationship and intra-regional economic activities are well supported by the following theoretical explanations.

\section{International Labour Division}

The international labour division in East Asia is not only a part of a larger global process of specialization, but also a good example of regional labour division. The most striking factor explaining the East Asian regional labour division is that, in East Asia, there are strong differences in the allocation of natural resources and industrial development level. Some industrially powerful countries are resourcepoor ones. Some resource-rich countries are industrially weak. Even among the industrialized countries, some are relatively more advanced in the level of industrialization than others. Therefore, we can find a vertical as well as a horizontal labour division in East Asia. The vertical labour division explains that the advanced economies in this region are the host countries for high-tech industries, whereas the less developed economies are the suppliers of cheap labour and resources. The horizontal labour division shows that the shedding effects from the advanced economies can be a great input to the less advanced economies in form of foreign direct 
investment, partial and gradual technology transfer and international subcontracting.

Taking into consideration the factors of resource, labour, capital and technology, East Asian sustained economic growth is a phenomenon based on rational flows of capital, mutual assistance and comparative advantage. Therefore, the international labour division in East Asia is the basis of regional economic cooperation and sustained economic growth.

\section{Advantageous Geographical Location}

To some extent the distribution of intra-regional industrial production depends on the geographical location and environment. A rational distribution of production must consider the geographical differences of each country in the region. The most important is how to maximize economic efficiency and distribute industrial production rationally. The intra-regional economic cooperation is therefore a means of geographical distribution of production.

For example, the division of industrial production demands a rational distribution of industries in each country and between regions based on the conditions of production cycles and closeness of raw materials. The division of transportation location requires a rational combination of raw materials, industrial zones and markets based on the consideration of reducing transportation expenses. The division of market location demands a rational formation of regional market zones based on product outlet possibilities and comparative advantages. This division of location is based on the dynamic comparative interest. According to this theory, the East Asian region must have an effective combination of international labour division, natural resources, transportation and market.

If we take a close look at China's recent economic growth, we will find that the economic expansion comes mainly from the special economic zones. These zones are almost all located along China's coastal provinces. The advantages of geographical location have certainly played a big role in promoting economic activities and trade between these zones and China's border countries or regions. For instance, exchanges and trade between Guangdong province and Hong Kong, Fujian province and Taiwan, and Shandong province and South Korea, are clear indications of enormous comparative advantages of geographical location. 


\section{Broad Mutual Benefits}

From a broader perspective, this theory can be regarded as combination of the above two theories. In the discussion of East Asian intra-regional economic relations it is necessary to point out that broad mutual benefits are the foundations for intra-regional cooperation. This theory proposes a rational and specialized coordination among states in the region. Whether or not this kind of specialized coordination can be done depends largely on the practical and mutual needs among countries in the region.

Mutual dependence and mutual benefits are always the driving force which promote specific international economic cooperation. It is exactly the differences and distances in terms of economic development level, technological level, industrial structure and natural resources that stimulate the mutual needs among countries and regions.

\section{The Dynamics of "Take-over", "Ladder" and "Chain" Pat- tern of Intra-Regional Economic Relations}

The East Asian style of economic development can be described as the result of four "industrialization waves." Japan was the only country in Asia that industrialized much earlier than the rest countries. Its modernization initiative and program can be dated back to the Meiji period when Japan faced the danger of Western invasion and colonization. After the Second World War, Japan started the first industrialization wave based on American capital and technology. Japan took the opportunities of the global economic restructuring, and gradually transformed itself from a defeated nation into the second largest economy in the world right after the United States.

The East Asian NICs played the major role in starting the second industrialization wave in which they inherited Japanese capital, technologies and mode of production, and within several decades they succeeded in achieving First World prosperity. The three dragons of ASEAN countries presented the third industrialization wave by taking the opportunities in the adjustments of production structures in Japan and the Asian NICs and by absorbing their investments and technologies. These three ASEAN nations are leading the global economic growth and they have been labeled as the "second generation of NICs". China's economic take-off in the 1980 s follow- 
Li Xing

ing its reform program can be regarded as the fourth industrialization wave in East Asia.

Figure 1. A Clear Ladder-Style Regional Economic Growth Model

Japan 1950s - 1980s

The East Asian NICs 1960s - 1980s - 1990s

ASEAN 1970s - 1990s

China 1980s - 1990s

Vietnam, Laos, Burma 1990s -..?

The above figure indicates that East Asia's ladder-type of intra-regional economic relations are well formulated both in time and space. In terms of development level, Japan stands at the top of the ladder and the rest stands at low or lower levels. In terms of economic relations countries at the lower end of the ladder are willing to "inherit" the "left-over" from countries at the top of the ladder by overtaking their industries and importing their technologies. This kind of closely linked intra-regional economic structure also explains the reason why economic growth is also "inherited" in East Asian countries. The peculiar phenomenon has been possible because the region has produced continuously, but never simultaneously, new players in the world economy. Thus, we can observe the interesting fact that countries in this region are at different stages of economic development, but they all share some fundamentally identical path of economic development.

The so-called chain-pattern economic development in East Asia is clearly the product of the interactions of the four industrialization waves. It has certain overlaps with the flying geese pattern of economic development put forward by Japanese leaders and intellectuals in the 1980s. The flying geese pattern mainly refers to the development levels and stages between countries in the region, while the chain-pattern reveals the structure of industrial production relations among countries in the region. The hypothesis of the flying geese pattern suggests that a group of nations in this region are flying together in layers with Japan at the top layer, the NICs at the middle and the rest at the bottom. The layers signify the different stages of economic development achieved in various countries. The hypothesis of chain pattern indicates that many products are going through 
processing in a number of countries, and economies in the leading position will gradually move some of their industries or industrial sectors to the next layer of countries because of changing comparative advantage over time. However, it is necessary to point out that this pattern of economic development is largely centred on. Japan and based on its production system.

When the Japanese economy entered a higher development stage focusing on high-tech industries and high value-added products, it transferred its labour-intensive and part of its capital- and technology-intensive manufactural industries to other East Asian countries, thus leaving itself at the far end in the spectrum of manufacturing and strengthening its character as a service-oriented economy. Following the rapid economic development of the first generation of East Asian NICs and the rise of their labour cost, they too transfered their labour-intensive and part of their capital- and technologyintensive industries to countries in Southeast Asia. In the past decade, China's open-door policies have attracted a large amount of foreign investment, and many labour-intensive and capital- and technology-intensive industries have moved to China. For instance, Hong Kong has moved almost its entire manufacturing industries to mainland China while continuing to act as a financial and service centre. Taiwan and mainland China have developed similar highly dependent economic relations in recent years.

\section{Historical Evolution}

It would be profoundly ahistorical to think that these "take-over", "ladder" and "chain" industrial relations in East Asia only occurred since the 1960s. An understanding of the political economy of these relations can only emerge from an approach that posits the systemic interaction of each country with the others, and of the region with the world at large. It is accordingly crucial to study East Asian political economy from 1900 to 1945 in order to understand the role of Japanese colonialism and capitalism in the evolution of East Asian economic relations.

Japan followed the path of the Western experience of colonization of the non-European world in the past centuries. Being afraid of becoming a dependency or perhaps even a colony of the Western powers, Japan resorted to maximize its relative advantages by seeking territories close to the homeland. Although it is clear that the colonial development was directed to serve the Japanese Empire rather 
than Korea and Taiwan themselves, some scholars argue that colonialism did have certain positive effects on the later development of Korea and Taiwan, and certain changes effected from Japanese colonialism were historic. ${ }^{4}$ At least Japanese imperialism had laid an infrastructural foundation for these countries' later industrialization.

Unlike other colonial powers Japan colonized its neighbouring countries in order to establish a close and tight regional economic integration. In Korea and Taiwan, Japan emphasized not only military control but also development under strong state auspices. Japan was also among the few imperial powers to locate modern heavy and light industries in its colonies: steel, chemicals, hydroelectric facilities, railways, roads, rice mills, textile factories, smelters, oil refineries, shipyards in Korea and some heavy industries in Manchuria where even today China's heavy industry is still located. It was during the colonial period that preliminary industrial relations was established in East and Southeast Asia.

Japan's "economic miracle" in the past four decades is the main source of inspiration in stimulating East and Southeast Asian nations and Japan is clearly the model for these Asian late-comers. They basically learned the development formula from Japan: low wages, high saving rates and strong government guidance of the private economy. Historically, there have been three main elements in East Asian industrial development which were based on Japanese model. The first was the development of a highly competitive manufacturing sector. The second was the deliberate restructuring of industry toward higher value-added and high-productivity industries, and in the late 1980s, these were mainly knowledge-intensive tertiary industries. The third element was aggressive domestic and international business strategies. When Japan entered a later stage, it passed the earlier phase to the Asian NICs who, in turn, passed their earlier stages to other developing countries as they entered a higher level.

\section{The Effect of Chain-Pattern of Intra-Regional Economic Relations and Divisions of Labour}

This take-over relation is formulated not in the form of rapid transfer of a total industry from one country to another but in the form of transfer of some particular industrial sectors or certain production processing units. The content of these tranfer interactions can be described as a "tutor-pupil" relationship. The economies, which transfer their industries or sectors to other countries, will simultaneously 
pass on their competitive technologies and management to them. As a result, based on their own comparative advantages those recipient countries will use the inherited industries to strengthen their competitiveness in the international market. The "learning effect" will eventually develop the "catching-up effect", and those late-comers will be able to advance their economic development and narrow the gap of income level and living standard to those of developed economies. Of course, it is important to point out that during the catching-up period, many additional factors influence the process of industrialization, i.e. the role of the state, culture, education, labour, etc. The first generation of Asian NICs, Taiwan, South Korea, Singapore, is an example of such an effect.

The chain-pattern of production relations in the region increases intra-industrial and intra-company cooperation. Gradually, more products are produced through different stages and sections in different countries based on comparative advantage. There are four stages of chain-pattern of production relations: (1) Early stage (food processing, textile and leather products); (2) Middle stage (nonmetallic minerals, rubber products, wood products chemical and petroleum refining, etc.); (3) Late state (clothing, basic house electronics, capital and intermediate goods); and (4) High-tech stage (biotechnology, information technology, hi-technology and material sciences). Japan is the only country which has entered the high-tech stage judging from its overall economic performance. The East Asian NICs have both the late and high-tech stages at the same time while the catching-up NICs have entered the late stage. At this point, to locate China's position is problematic because of the country's vast size and unbalanced development level between different regions. It is difficult to clearly define the stage where China is positioned because all the different stages can be found there. Although, on the one hand, this signifies the unbalanced development of China's domestic economy, on the other hand, the advantages of China's multilevel economy enable it to cooperate with countries of different stages at the same time; and different Chinese provinces can give full play to their comparative advantages.

Although the intra-regional economic interdependence has the appearance of a well-tuned harmonious construction, close examination makes contradictions apparent. The fact that the final products of different stages go through production processes in many coun- 
tries in the region indicates that this new division of labour is both horizontal in the sense that the entire industry or production line is passed on, and vertical in another sense that the sub-processes may be passed on to other countries. Although East Asia is clearly increasing its economic interdependence it must be seen that the region's economies are not in well-balanced harmony, but are more in competition with one another than complementary in labour cost, labour talent, seeking markets for export, technological upgrading, etc.

The chain-pattern of production relations among East Asian states also reveals a similar model of their labour relations. The international labour division of production is well-defined among Japan, the NICs and ASEAN states. In the past few years, a very sophisticated pattern of specialization has emerged. While Taiwan and South Korea have specialized in the highly capital and technologyintensive productions, Hong Kong and Singapore have done so in the highly skill and equipment-intensive design and testing stages; and on the other hand, the Philippines, Thailand and Malaysia have concentrated on the highly labour-intensive assembling stage ${ }^{5}$.

In this connection, one interesting point worth mentioning is China's production and labour relations with other Asian states. As mentioned above, the nation's vast size and unbalanced development level between different regions indicate that it is flying in different layers simultaneously and has multiple chain production and labour relations with many countries. This situation is obviously an advantage because it enables China to cooperate with other countries in almost all industrial sectors. On the one hand, China is capable of cooperating with Japan and the NICs in developing hightech industries while it can inherit labour-intensive industries from them. On the other hand, it can also export capital, intermediate products and some of its labour-intensive light industries to less developed countries in the region. Based on these closely linked economic relations, Chinese economy is increasingly integrated with the regional economy. As Morrison and Whiting point out, "In contrast to the fears of China as an economic competitor, which dominated perceptions of China's role at the beginning of the modernization program, Asia-Pacific countries in general have found that they have successfully adjusted to China's integration into the regional economic system without serious negative repercussions to them. ${ }^{16}$ 


\section{Regional Reactions}

East Asian nations outside Japan have viewed this chain-pattern production relations and flying-geese pattern of development with mixed feelings. On the one hand, the image of Japan as a cruel aggressor during the Second World War has created emotional obstacles against strengthening their political and economic relations with Japan. The flying-geese formation and the chain structure of production, it seems to them, offer little hope of closing the gap with Japan at any time in the near future. In fact, East Asian countries are deeply ambivalent and suspicious about their economic relationship with Japan. On the other hand, it is an undeniable fact that the Japanese market, investment and economic activities are becoming increasingly indispensable to regional economic development. The most conspicuous feature of Japanese economic relations with Asia is demonstrated by the fact that by 1990 Japan had become the dominant foreign economic actor in three of the developing countries of the Association of Southeast Asian Nations (ASEAN), namely Indonesia, Malaysia and Thailand, and likewise Japan approximately balanced the overall US trade, aid, and investment presence in the Philippines.

\section{The Dynamics of Intra-Regional Market and Trade}

The success story of the Asian NICs' export-oriented economic development is well documented. It has also been widely recognized that the engine of economic growth in the NICs' model lies especially in rapid growth in exports. In fact, the NICs' success story is primarily a story of successful export growth. Statistics indicate that when there is high export growth, the national economy grows fast. The explosive expansion of China's coastal provinces is a good example of the export-led strategy.

Thanks to the favourable international development situation, the export-oriented strategy was especially successful in the 1960s and 1970s, when the NICs could easily specialize in the production of labour-intensive goods with free access to export markets in Western industrially advanced countries. The potential of the US market starting with the Korean War, and sustained until the end of the Vietnam War helped the economies of Japan and the NICs grow at an unprecedentedly high rate. After the Vietnam War, the US econ- 
omy weakened but still played a key role by providing the largest market for the industrial exports of East Asia.

However, the transformation of the post-Cold War international political economy - the relative decline of the US economy, the rising protectionism in Europe and the establishment of two Western economic blocks - indicates that the reliance on Western markets by both the Asian NICs and the late-comers can no longer be taken for granted. The future of the international trading system is uncertain. The whole world is undergoing a major shift in comparative advantage. As a result, major industrial powers are facing the painful task of making structural adjustments. The social and political problems which result from huge trade imbalances among major advanced countries are pushing them away from free trade into protectionism. This world-wide protectionism is aiming not only at Japan but also at the NICs' expansion of exports. It is directed especially at the lowcost labour-intensive light manufactured products, which major developing countries expect to make their leading exports.

\section{The Emergence of Intra-Regional Market and Trade}

In order to avoid the situation of over-dependence on Western markets, Asian countries are left with one crucial prospect - to gradually shift the direction of their exported-oriented strategy towards more intra-regionally directed trade relations. Recent studies have indicated that a network of interdependence and intra-regional trade is emerging. Although East Asian economies still rely on exports to the industrial countries as an important engine for growth, intraregional trade and internal demand play an increasing role in their development. Domestic markets have been driven by the rapid growth in personal incomes and by needed infrastructure investments. If we look at the whole Asia-Pacific region, trade within the region has been increasing dramatically in comparison with other parts of the world. In 1992, the total US trade volume in the AsiaPacific region reached $\$ 534$ billion in which its trade with East Asia accounted for $\$ 348$ billion. This was far more than the US trade with Canada and Mexico (\$265 billion) and Europe (\$227 billion). ${ }^{7}$ During the end of 1980s, 70 percent of the export of the Asian NICs' and 68 percent of its import were conducted within the region. Similar indications of increasing intra-regional trade can be found with 72 percent of ASEAN export and 63 percent of its import; 62 percent of Japan's export and 57 percent of its import; 46 percent of the US export 
and 53 percent of its import; 82 percent of Canada's export and 77 percent of its import; China, whose total trade volume was $\$ 111.6$ billion in 1989 in which its Asia-Pacific trade was 66 percent of the total import volume and 75 percent of the total export volume. ${ }^{8}$

While the expansion of world trade has slowed down and the extent of protectionism has increased in most developed countries, it is however very remarkable that East Asian states are creating new markets in their own region. Intra-regional trade expansion in East Asia is particularly evident in the areas of the Golden Triangle of Southeast Asia (consisting of parts of Malaysia, Indonesia, and Singapore), in the South China Zone comprising Hong Kong, Taiwan and China's southern provinces, and in the area of the Yellow Sea including Japan, South Korea and China's northern provinces.

Japan's recent economic recession and its troubled economic relationship with the US is pushing it to seek salvation near to home. Southeast Asia and China now purchase 34 percent of total Japanese exports, while the United States buys 28 percent. Japan's manufacturing agreements with ASEAN countries also ensure that almost all of the two million cars the region will need annually by the year 2000 will come from Japanese joint-ventures. According to the 1993 World Bank report, developing Asia is now the largest and the most rapidly growing market for Japan.

Table 1. Changing Pattern of Japanese Exports (billions of US\$)

\begin{tabular}{|l|r|r|r|r|}
\hline & 1988 & 1989 & 1990 & 1991 \\
\hline Total & 264.9 & 274.6 & 287.7 & 314.9 \\
\hline U.S. & 90.2 & 93.9 & 91.1 & 92.2 \\
\hline East and Southeast Asia & 77.4 & 82.6 & 90.1 & 105.9 \\
\hline EC & 47.2 & 48.0 & 54.0 & 59.6 \\
\hline
\end{tabular}

Source: East Asia and the Pacific Regional Development Review - Sustaining Rapid Economic Development (Washington: The World Bank, 1993), p. 37.

The above table indicates that Japan's exports to the United States stagnated at around $\$ 90$ billion over 1988-91, while its exports to Asia increased by 37 percent to reach $\$ 106$ billion in 1991. About 60 percent of the increase in Japanese exports in 1991 flowed to Asia. In the 1990s, Japan might have to rely heavily on East Asia for export markets, which will be further facilitated by increased capital flows from Japan. 
The region's growth of exports slowed during the 1980s, but most countries are still reporting handsome gains. With US economy declining, Asian nations are benefiting from their efforts to develop new markets in Europe and have bolstered trade ties with partners in their own region. Intra-regional trade will continue to grow as these countries become more dependent on each other rather than the USA or Japan. For example, Taiwan shipped nearly half its exports to the USA in the mid-1980s; by 1991 the figure will be less than 30 percent. Meanwhile, Taiwan's shipments to Hong Kong (which eventually find their way into mainland China) rose 50 per cent in 1991 over the 1990 figure.

\section{The Rise of the Chinese Market}

China used to be regarded as a vast "theoretical market", but its recent high growth rate and an emerging affluent middle class have already made that label outdated. Rather, it is now globally regarded as a potential "practical market." In China's coastal provinces and other more developed areas, per capita income is in fact very much within the range of the middle income countries in the classification of the World Bank. China's official figure of per capita GNP is US $\$ 370$, but Guonan Ma and Ross Garnaut of the Australian National University suggest that China's economy may be two to three times larger than official estimates. Rather than US\$370, per capita Chinese income could be $\$ U S 700-1,000$, or more. Rather than being a low-income country grouped with India and Haiti, this would make China a middle-income country approaching the per capita income of Thailand. And it would make China the world's fourth largest economy, behind Germany but ahead of Britain. ${ }^{9}$

China's increasing purchasing power can no longer be neglected. It has been officially confirmed that from now on to the end of this century, China's yearly import volume will be more than US $\$ 100$ billion. In 1994, China's imports reached a record of US $\$ 114.6$ billion and China's exports amounted to US $\$ 119.8$ billion. ${ }^{10}$ The economic future of China and the outside world are inextricably linked. For example, China's enormous demand for steel, caused by its nationwide construction boom, made world steel prices increase by ten to fifteen percent during six months between 1992 and 1993. China is gradually becoming a fourth pole in the world economy and this is particularly true if we look at "Greater China", consisting of mainland China, Taiwan, Hong Kong and the overseas Chinese com- 
munities. Greater China is becoming a trade power in its own right. Disregarding the trade among Chinese economies, which has tripled in the past fifteen years, their collective trade accounts for nearly five percent of world trade, up from 1.8 per cent in $1980 .{ }^{11}$ Only the US, Germany and Japan each have a substantially bigger share.

\section{The Dynamics of Intra-Regional Capital Market and In- vestment}

The situation of supply and demand of the global capital market in the 1990s will be characterized by overwhelming demand for capital and direct investment in most of the world. One of the most successive development experiences of East Asia is to take the advantage of foreign direct investment, not only in terms of capital itself, but also in terms of foreign technology, management and advanced information system. The demand for foreign capital and investment in the region is not decreasing but will continue to grow.

East Asia is increasingly becoming a favourite target of foreign direct investment. East Asia, for example, accounted for about sixteen percent of total foreign direct investment flows to developing countries in the 1970s. In the 1980s, its share had more than doubled. There are some reasons for this increase. One important reason is due to China's emergence as a favourite target for direct foreign investment: wages in coastal China are only a fifth of the average wage in Hong Kong and 70 percent of that in Malaysia; the average cost of factory construction in Hong Kong is more than five times that in Zuhai, a special economic zone in Guangdong Province. In 1993, foreign direct investment (FDI) to China rose to more than US $\$ 20$ billion, making it the largest single recipient of FDI in the developing world. ${ }^{12}$

Table 2. East Asia's Share of Total Foreign Direct Investment to Developing Countries (in \%)

\begin{tabular}{|l|r|l|r|}
\hline \multicolumn{2}{|c|}{$1970-79$} & \multicolumn{2}{c|}{$1980-90$} \\
\hline Latin America & 53.7 & Latin America & 42.0 \\
\hline East Asia & 16.1 & East Asia & 33.2 \\
\hline Sub-Saharan Africa & 14.7 & Sub-Saharan Africa & 6.7 \\
\hline Others & 15.5 & Others & 18.1 \\
\hline
\end{tabular}

Source: East Asia and the Pacific Regional Development Review - Sustaining Rapid Development, p. 35. 
Foreign direct investment (FDI) inflow to developing countries in the Asian and Pacific region has continued to grow. In 1994, the inflow was conservatively estimated at about US $\$ 52$ billion, a quantum jump over US $\$ 30$ billion recorded in $1992{ }^{13}$

The sources of capital and investment to the region have also changed. The US and Western Europe used to be the main sources of FDI to East Asia. However, in the 1980s Japanese foreign direct investment grew rapidly and accounted for between a third and a half of all such flows to East Asia. More importantly, Japan has inherited America's role as the world's largest creditor nation. In contrast, the United States is now the world's largest debtor nation; a debt which is expected to continue to balloon. Taiwan, with its foreign exchange reaching more than $\$ 100$ billion, is another emerging "investment bank" in East Asia.

\section{The Dominance of Japanese Investments}

Recent studies indicate that the newly industrialized economies together with Japan are displacing the US and EC as the dominant sources of foreign aid and investment.

Japanese foreign aid has recently attracted considerable attention. East Asia is the major recipient of Japanese foreign aid in the form of financial loans. In 1993 East Asia received 60 percent of Japanese bilateral aid. By geographic region Africa occupied second place with 12 percent, Central and Latin America received nine percent and the Middle East six percent. East Europe is a low priority region for Japan and received only 1.5 percent.

Table 3. Main Recipients of Japanese Foreign Aid in Fiscal 1993 (billions of US\$)

\begin{tabular}{|l|c|c|}
\hline Country & Amount Bilateral Aid & Share of Total (\%) \\
\hline 1. China & $1,350.67$ & 16.54 \\
\hline 2. Indonesia & $1,148.89$ & 14.07 \\
\hline 3. The Philippines & 759.39 & 9.29 \\
\hline 4. Thailand & 350.15 & 4.29 \\
\hline 5. India & 292.90 & 3.62 \\
\hline
\end{tabular}

Source: The Japanese Foreign Ministry, "Waga Kuni no Seifu Kaihatsu Enjo 1994."

The above top five countries receiving most aid are all Asian countries and in total these five received 48 percent of total bilateral Japanese aid. 
As indicated by Table 4, Japan is increasingly playing a leading role in the economic development of East Asia, which is the direct beneficiary of Japanese direct investment, financial aid and local employment. For a long period since the end of Second World War, Japan was regarded as "breaking away from Asia and joining the West". Is the strategic and structural adjustment undergoing in Japan today an indication that Japan is trying to "reenter Asia"?

Table 4. Japanese Exports, Direct Investment and Employment of Local People in East Asia

\begin{tabular}{|l|c|r|r|r|c|}
\hline Countries & \multicolumn{2}{|c|}{$\begin{array}{l}\text { Japanese Exports } \\
\text { (billions of US\$) }\end{array}$} & \multicolumn{2}{|c|}{$\begin{array}{c}\text { Japanese Direct } \\
\text { Investment } \\
\text { (millions of US\$) }\end{array}$} & $\begin{array}{c}\text { Number of Em- } \\
\text { ployees in Japan- } \\
\text { owned companies }\end{array}$ \\
\hline & 1983 & 1992 & 1983 & 1992 & \\
\hline China & 4.9 & 11.9 & 114 & 1,070 & 82,708 \\
\hline Taiwan & 5.1 & 5.1 & 103 & 292 & 168,154 \\
\hline ROK & 6.0 & 17.8 & 129 & 225 & 203,484 \\
\hline Hong Kong & 5.3 & 20.7 & 563 & 735 & 74,164 \\
\hline Thailand & 2.5 & 10.4 & 72 & 657 & 211,286 \\
\hline Philippines & 1.7 & 3.5 & 65 & 160 & 66,014 \\
\hline Malaysia & 2.8 & 8.1 & 140 & 704 & 150,716 \\
\hline Singapore & 4.4 & 13.0 & 322 & 670 & 92,360 \\
\hline Indonesia & 3.6 & 5.6 & 374 & 1,676 & 120,136 \\
\hline
\end{tabular}

Source: Newsweek, August 30, 1993.

\section{The Rise of Taiwanese Investment}

Taiwan is the second largest supplier of capital and investment in the region. In the 1970s and early 1980s, little attention was paid to the potential economic role that Taiwan might play in regional political and economic relations in East and Southeast Asia. Taiwan's economic performance in the past two decades has begun to attract a great amount of international attention as Taiwan is integrating into the larger world and regional economic system. Taiwan's rapid industrial advancement during the past four decades has come to be known as the "Taiwan Experience" or "Economic Miracle." The island is emerging as one of the major economic and trade powers in the world. Taiwan's per capita GNP is rising to a record high of US $\$ 12,944$ in 1995, up from the US\$11,604 registered in 1994; and its 
Li Xing

per capita GNP measured in terms of purchasing power parity reached US $\$ 15,380$ in 1993, the 20th-highest in the world. ${ }^{14}$ Taiwan's foreign trade reached a record high of US\$178.4 billion in 1994, making the island the 14th-largest trader in the world; and the 1995 trade figure is expected to be over US\$200 billion. ${ }^{15}$

Another significant figure concerns Taiwan's foreign exchange reserves. Statistics released by the Central Bank of China show Taiwan's foreign reserves exceeded US $\$ 100$ billion and reached US $\$$ 100.3 billion as of the end of May 1995, ranking the island as the second-largest in the world after Japan's US $\$ 150$ billion. ${ }^{16}$ Particularly in terms of capital export and direct investment, Taiwan is increasingly playing a new and larger role in the region. Its greater economic role together with its emerging political influence brought by the strong economy is challenging the status-quo bilateral relations with the US, Japan, Europe and especially with East Asia.

Traditionally, the United States was the primary target for Taiwanese investment. But, following the weakening of the US economy with its high labour costs and slow growth, Taiwanese investors began to look for other areas to place their capital. Considering overall factors, Taiwan investors obviously regarded East Asia as their first choice to direct their investments and relocate their labourintensive industries. For example, by the year 1990, the total volume of Taiwanese investment in Southeast Asia exceeded its investment in the United States and this trend continued into 1991. In Malaysia, Taiwanese investment which amounts to half of Malaysia's total foreign investment of US $\$ 0.8$ billion (M $\$ 2.16$ billion), overtook the Japanese in 1989. In Indonesia, Taiwan's investment began to pour in by 1990 . In 1989, the amount was only US $\$ 2$ million. By 1990, it had increased to US\$61.9 million and in 1991 it jumped up to US\$160 million, ${ }^{17}$ and this rising trend seems to be continuing.

Taiwan's heavy investment in mainland China is the most striking phenomenon in the region. Since the late 1980s Taiwanese indirect investment in mainland China through Hong Kong has been pouring into China's southern provinces. In the middle of 1992, the Chung Hwa Institute for Economic Research in Taipei estimated that total investment was about US $\$ 5$ billion, which is more than that of the US and Japan combined. ${ }^{18}$ It should be noted that these figures are official and legal, the actual size of Taiwanese investment could 
be much larger because many private companies channel their money out of Taiwan in order to avoid government taxes.

Thus, it appears safe to assume that foreign investment which is needed for economic development in East Asia will be increasing rather than decreasing. This is because the two capital-rich nations, Japan and Taiwan, are located in this region and they are both relocating their investments to this region.

\section{Prospect of Sustained Economic Growth}

Without dramatic international political turmoil, the world economy could possibly experience an upward tendency of the economic growth rate, and East Asian economies are no exception. Many people and countries in East Asia are wondering what will the regional economic development trend be and what could the possible causes of regional economic slow-down be from now to the year 2000 and beyond.

If we extend our vision to the whole of the Asia-Pacific region, our optimism about the future regional economic development is not unwarranted. According to statistics and predictions from certain international economic organizations, the average economic growth rate of the AsiaPacific economies in the past 20 years is six percent; and that is double as much compared with the rest of the world in the same period. ${ }^{19}$ However, the term "Asia-Pacific economy" has a large context, and it should be divided into relatively advanced economies such as the US, Japan and the NICs and relatively less advanced ones. Most industrialized countries in the region including the US and Japan are facing economic stagnation, but they would possibly be able to keep an medium-to-low economic growth rate in the years to come. 
Li Xing

Table 5. Growth Prospects for the Different Developing Regions 1980-2000 (average annual growth in percent)

\begin{tabular}{|l|c|c|c|c|}
\hline & \multicolumn{2}{|c|}{ GDP } & \multicolumn{2}{c|}{ GDP per Capita } \\
\hline & $1980-89$ & $1990-2000$ & $1980-89$ & $1990-2000$ \\
\hline All developing countries & 3.7 & 4.9 & 1.6 & 2.9 \\
\hline Sub-Saharan Africa & 2.0 & 3.6 & -1.2 & 0.5 \\
\hline East Asia & 7.9 & 6.7 & 6.2 & 5.2 \\
\hline South Asia & 5.4 & 4.7 & 3.0 & 2.6 \\
\hline $\begin{array}{l}\text { Europe, Middle East and } \\
\text { North Africa }\end{array}$ & 2.5 & 3.6 & 0.4 & 1.5 \\
\hline Latin America & 1.7 & 3.8 & -0.4 & 2.0 \\
\hline
\end{tabular}

Source: The World's Emerging Markets (London: Euromonitor, 1992), p. 94.

The Asia-Pacific economies, especially those of East Asia will most probably continue to have a higher growth rate than that of other parts of the world, for instance, Latin America and Africa (see table 5). Both the US and Japan belong to the economies of the Asia-Pacific region. The US economy which had an average growth rate close to 2.7 percent has dropped to a rate of 1.7 percent, and is striving to reach a growth rate close to 2.5 percent or 3 percent in the late $1990 \mathrm{~s}$. Japan's average growth rate was 4.1 in the 1980s and was only 1.4 in the first half of the 1990s, but Japan could possibly regain its economic strength in the second half of the 1990s. ${ }^{20}$

Among all the global emerging economies, the East Asian economies will be the fastest growing although the growth rate in the 1990s will be slower than the 1980s. There will most likely be a new order among the growth leaders within this region. The traditional Asian NICs such as Taiwan, Singapore, and South Korea will find it harder to keep up their previous high growth records. Whereas other countries such as China, Malaysia and Thailand will replace them as growth leaders. Various studies of the seven East Asian Economies - Hong Kong, Singapore, South Korea, Taiwan, Malaysia, Indonesia, and Thailand - have conclusively indicated that high savings rates, disciplined government fiscal policies, strong investment in education, technology transfers, and export promotion are important common elements behind their rapid economic growth. In 1993-94, they expanded between five and eigth per cent, and similar economic performances are expected in the following years. 
China has increasingly become the engine of growth in the region. Since the beginning of the 1990s, China's economy has gradually been developing into a market economy, dubbed "socialist market economy" in the Chinese discourse. The Chinese economy is huge and is thriving rapidly - more than thirteen percent annual growth in 1992 and 1993. Using purchasing power in adjusted exchange rates instead of market exchange rates, the IMF has estimated that China ranks just slightly behind Japan in terms of total output. The Chinese economy is forecast to grow less rapidly in the coming years than in the previous years, largely due to government efforts to reign in unproductive investment and cool down the soaring inflation.

Global attention is being drawn to the rapid expansion of the Chinese economy. China's increasing investment flows, both in and out of the country, are major aspects for the importance of trade in East Asia. According to the 1993 World Bank report on developing countries, the increasing role of a Chinese economic area, the so-called fourth growth pole (in addition to the US, EU and Japan), is expected to provide sustained long-term development that will strongly benefit other economies, not only in the region but elsewhere as well.

Table 6. An Assessment of Relative Prospects in Emerging Economies

\begin{tabular}{|l|l|l|}
\hline $\begin{array}{l}\text { Particularly good } \\
\text { market prospects }\end{array}$ & $\begin{array}{l}\text { Good market } \\
\text { prospects }\end{array}$ & $\begin{array}{l}\text { Moderately good market } \\
\text { prospects }\end{array}$ \\
\hline China & Argentina & Brazil \\
\hline Indonesia & Mexico & Chile \\
\hline Kuwait & Pakistan & Egypt \\
\hline Malaysia & Portugal & Hungary \\
\hline Thailand & South Korea & Iran \\
\hline Venezuela & Taiwan & Singapore \\
\hline & & South Africa \\
\hline & & Zimbabwe \\
\hline
\end{tabular}

Source: The World's Emerging Markets, p. 40.

Table 6 shows that among the six countries which are regarded as most promising in terms of market prospects, four of them are in East and Southeast Asia. Among countries which are labeled as having good market prospects, three out of six are in Asia.

Economic data tell us that East Asia is the clear winner in the global competition for investments and markets. Furthermore, eco- 
nomic forecasts indicate that at the end of this century Asia's estimated 400 million affluent middle class will have a purchasing power at the average level of West European and American middle class. The sign is somehow clear that at the beginning of next century East Asia will most likely replace the US and Europe as the largest consumer market in the world.

\section{Future Constraints and Challenges}

However, besides the optimism of East Asian economic future, several uncertain factors might pour cold water on the prospect for sustained economic development in East Asia. First, the end of the Cold War, with the disappearing of the balance of power among world powers, may pave the way for traditional international conflicts over territories and natural resources. East Asia and the Pacific region is no exception. Severe economic competition and rapid economic growth in this region have intensified rising competition for fish, petroleum, gas and other resources; and countries in this region, weak or powerful, rich or poor, are seeking ways to extend their power beyond their territorial waters. The Spratley Islands are at present the hot spot for possible confrontations among a number of countries.

Second, the coming into existence of the two largest regional trading blocks, the EU and NAFTA is putting East Asian economies under tremendous dual pressure. On the one hand, the exclusivism of the two regional trading blocks will possibly affect the economic development potentials of East Asian export-oriented development policy. Even though the intra-regional interdependence is increasing, East Asia is still not able to change the situation of dependence on the US and European markets, at least in the near future. Therefore, the economies of East Asia will be the largest victim of the rising protectionism. On the other hand, the increasing power of these two trading blocks in competition for world markets can reduce the significance of East Asian economic power in the world economy. As a result, the East Asian economy might be forced to develop in the direction of multi-polars and dissolution rather than in the direction of integrated development.

Third, among economically powerful and vibrant regions of the world, the East Asian region seems to be the only one which has not established any institutionalized arrangement in the process of re- 
gional cooperation. East Asian intra-regional promotion of trade has been taking place in the absence of formal institutional structure in the framework of markets. Efforts toward institutionalizing regional economic relations and co-operation as seen in such moves as PECC (The Pacific Economic Co-operation Conference) and APEC (AsiaPacific Economic Co-operation) will continue, although full-scale regional economic institutions are unlikely to be established, at least for the time being.

\section{Final Remarks}

Despite of severe challenges ahead for the region, East Asian dynamism is projected to continue. The region is in the transition from dependent growth to self-sustaining growth. The tendency of regionalization in trade and investment is still strong. The increased economic interactions are the result of their economic expansion by seeking for economic comparative advantage. The political incompatibilities are gradually giving way to economic complementarities. The reforms and transformations of socialist states and the regional economic liberalization in the wake of political relaxation have promoted new cooperation and complementarities among these economic structures. East Asian economies are becoming more interdependent than ever.

The spectacular economic growth in East Asia has raised optimistic outlook for the future of East Asian and Pacific economy. Some scholars have an optimistic outlook for the Asian Pacific economy as a whole basing this optimism on the prediction of the emergence of a Pacific Century. Professor Chen states: "By the Pacific Century, we mean a shift of the world's centre of economic activities away from the two coasts of the Atlantic to the two coasts of the Pacific." ${ }^{121}$ Today the prediction that the 21st century will be the Pacific Century is widely accepted and many people indeed believe that the Pacific Century has already started. The present article should be seen in this perspective.

In a word, East Asia has been at the leading edge of economic development in many respects in the past decades. The overall economic attainment, and the size and dynamism of the East Asian and Pacific region have brought about the emergence of the region as an 
Li Xing

increasingly important economic power in shaping the future of the international political economy.

Li Xing is a Research Fellow at the Centre for International Studies, Aalborg University. The author is grateful to Professor Jacques Hersh and Editor Kjeld Erik Brodsgaard for their valuable and constructive comments.

\section{NOTES}

1 The term "East Asia" in this article refers to the eastern part of Pacific Asia, including the Far East and Southeast Asia.

2 NICs stands for Newly Industrialized Countries. NIEs stands for Newly Industrialized Economies. These two abbreviations are often used interchangeably.

3 Kim Chungsoo, "Economic Cooperation in Northeast Asia" in The Korean Journal of International Studies, Vol. xxii, No. 1 (Spring 1991), p. 56.

4 Bruce Cumings, "The Origins and Development of the Northeast Asian Political Economy: Industrial Sectors, Product Cycles, and Political consequences" in Frederick C. Deyo, ed., The Political Economy of the New Asian Industrialism (Ithaca: Cornel University Press, 1987), pp. 51-55.

5 K.Y. Edward Chen, "East and Southeast Asia in the World Economy: Issues, Problems, and Prospects" in Copenhagen Papers in East and Southeast Asian Studies, No, 4. (1989), p. 22.

6 Charles Morrison and Allen S. Whiting, "China's Role in the AsiaPacific Region" in Mark Borthwick, ed., Pacific Century - The Emergence of Modern Pacific Asia, (Boulder, Colorado: Westview Press, 1992), p. 456.

7 Li Changiiu, "The Rise of the East Asian Economies and the External Shift of the Gravity of the US Foreign Trade
Relations," Ya Tai Yanjiu, Vol. 3, No. 1 (1994), p. 44.

8 Zhang Haiming, "An Inquiiry into the Basis of Economic Cooperation of Asia-Pacific Region," Ya Tai Yanjiu, Vol. 3, No. 1 (1994), p. 25.

9 Australian Financial Review, September 11, 1992.

$10 \mathrm{IMF}$, Direction of Trade Statistics (Washington, D.C.: IMF, 1995).

11 Newusweek, November 15, 1993.

12 IMF, World Economic Outlook, (Washington, D.C.: IMF, October 1994).

13 Economic and Social Survey of Asia and the Pacific 1995 (New York: United Nations, 1995), p. 31.

14 Taiwan Factbook, China Economic News Service, Taiwan, 1995.

$15 \mathrm{Ibid}$

$16 \mathrm{Ibid}$.

17 Ho Khai Leong, "The Changing Political Economy of Taiwan-Southeast Asia Relations" in The Pacific Review, Vol. 6, No. 1 (1993), p. 32.

18 Ibid., p. 36.

19 Zhang Haiming, "An Inquiry into the Basis of of Economic Cooperation of Asia-Pacific Region," p. 24.

20 Gao Lianfu, "The Economic Development Trend of Asia-Pacific Region in the 90s," Ya Tai Yanjiu, No. 3, 1994, p. 19.

21 K.Y. Edward Chen, "East and Southeast Asia in the World Economy," p. 19. 